\title{
No Genetic Association between Polymorphisms of Heme Oxygenase 1 and 2 and Alzheimer's Disease in a Japanese Population
}

\author{
Nobuto Shibata Tohru Ohnuma Hajime Baba Heii Arai \\ Department of Psychiatry, Juntendo University School of Medicine, Tokyo, Japan
}

\section{Key Words}

Alzheimer's disease - Apolipoprotein E • Heme oxygenases • Polymorphisms

\begin{abstract}
Background/Aims: Recently, it has been shown that the heme oxygenases HMOX1 and HMOX2 might play a role in the pathogenesis of Alzheimer's disease (AD). Methods: To investigate whether there is any association between the HMOX1 and HMOX2 genes and $A D$, five single nucleotide polymorphisms (SNPs) in each gene were genotyped in 180 AD patients and 132 age-matched controls using TaqMan technology. Results: Our study failed to detect any association between the SNPs of the HMOX1 and HMOX2 genes and AD. In addition, we did not observe any synergetic association between the SNPs studied and apolipoprotein $\mathrm{E}$ in our AD patients. Conclusion: Further genetic studies are needed to clarify the relationship between the two genes and $A D$.

Copyright $\odot 2009$ S. Karger AG, Base
\end{abstract}

\section{Introduction}

Alzheimer's disease (AD) is the most common neurodegenerative disease causing dementia. The main pathological feature of $\mathrm{AD}$ is the formation of senile plaques

\section{KARGER}

Fax +41613061234 E-Mail karger@karger.ch www.karger.com
(C) 2009 S. Karger AG, Basel

$1420-8008 / 09 / 0273-0273 \$ 26.00 / 0$

Accessible online at:

www.karger.com/dem containing aggregated amyloid $\beta$ peptide. Three genes have been identified as causative genes in familial AD, the amyloid precursor protein (APP), presenilin-1 and presenilin-2. In addition, the apolipoprotein $\mathrm{E}$ (ApoE) e4 allele is the only recognized genetic risk factor for familial as well as sporadic AD. Although many studies have reported associations between genes involved in cholesterol metabolism and $\mathrm{AD}$, the functional connection between the cholesterol pathway and $\mathrm{AD}$ pathology has not been clearly resolved.

Several studies have reported that changes in heme metabolism and oxidative stress may be involved in the pathogenesis of AD [1,2]. Previously, it has also been shown that the accumulation of iron in neurons is associated with neuritic plaques in AD. Furthermore, iron might affect plaque formation through its effect on APP processing by modifying the function of $\alpha$-secretase [36]. Polymorphisms in several iron-related genes have been reported to increase the risk of sporadic $\mathrm{AD}$ [7]. Mutations in the PLA2G6 gene, which encodes phospholipase $\mathrm{A} 2$, were found in $\mathrm{AD}$ patients with high levels of brain iron [8]. Two polymorphisms, C282Y and H63D, of the hemochromatosis (HFE) gene, as well as an increase in the $\mathrm{C} 2$ variant of the transferrin gene have also been implicated in AD development [9-15].

The heme oxygenases HMOX1 and HMOX2 play important roles as antioxidant enzymes and are involved in heme catabolism [16]. Moreover, several studies have 
Table 1. Distribution of HMOX1 polymorphisms in AD and control groups

\begin{tabular}{lllrrrr}
\hline All cases & HMOX1 & & AD & $\begin{array}{c}\text { Con- } \\
\text { trols }\end{array}$ & $\chi^{2}$ & $\begin{array}{l}\text { p } \\
\text { value }\end{array}$ \\
\hline rs2071747 & exon 1 & C/C & 1 & 2 & 1.37 & 0.50 \\
& (H/D) & C/G & 32 & 19 & & \\
& & G/G & 145 & 111 & & \\
\hline rs2071748 & intron 1 & A/A & 37 & 34 & 1.60 & 0.45 \\
& & $\mathrm{~A} / \mathrm{G}$ & 102 & 66 & & \\
& & $\mathrm{G} / \mathrm{G}$ & 41 & 32 & & \\
\hline rs2071749 & intron 3 & $\mathrm{A} / \mathrm{A}$ & 12 & 17 & 3.49 & 0.17 \\
& & $\mathrm{~A} / \mathrm{G}$ & 91 & 62 & & \\
& & $\mathrm{G} / \mathrm{G}$ & 77 & 53 & & \\
\hline rs5755720 & intron 4 & $\mathrm{A} / \mathrm{A}$ & 47 & 39 & 6.63 & 0.08 \\
& & $\mathrm{~A} / \mathrm{G}$ & 98 & 62 & & \\
& & $\mathrm{G} / \mathrm{G}$ & 30 & 31 & & \\
\hline rs5995098 & intron 4 & $\mathrm{C} / \mathrm{C}$ & 48 & 42 & 3.69 & 0.16 \\
& & $\mathrm{C} / \mathrm{G}$ & 100 & 59 & & \\
& & $\mathrm{G} / \mathrm{G}$ & 32 & 31 & & \\
\hline
\end{tabular}

shown a synergetic association between HMOX1 and APP [17-19], while HMOX2 has been reported to play an active role in neuroprotection [20].

Although one study of a microsatellite marker within the HMOX1 gene promoter region failed to find any association with $\mathrm{AD}$ [21], polymorphisms in the HMOX1 and HMOX2 genes have not been fully studied in $\mathrm{AD}$ patients. We therefore investigated the possible relationship between polymorphisms of the HMOX1 and HMOX2 genes and sporadic AD.

\section{Materials and Methods}

DNA was extracted from white blood cells using a standard method. Sporadic Japanese AD cases $(n=180$, male:female ratio $=79: 101)$ were recruited from the in-/outpatients of our hospital. The mean age $( \pm S D)$ at the time of examination of the $\mathrm{AD}$ group (67.4 \pm 6.2 years) was not significantly different from that of the control group (64.4 \pm 6.7 years). All the $\mathrm{AD}$ cases were diagnosed according to the NINCDS-ADRDA criteria and none had a familial history of AD. The control cases $(\mathrm{n}=132$, male:female ratio $=63: 69)$ were obtained from healthy volunteers with no history of dementia or any other neuropsychiatric disease. We could not confirm whether these individuals have any family history of dementia. The purpose and significance of the study were explained in detail to each patient and his/her family, and all subjects provided their informed consent. The study protocol was
Table 2. Distribution of HMOX2 polymorphisms in AD and control groups

\begin{tabular}{lllllll}
\hline All cases & HMOX2 & & AD & $\begin{array}{l}\text { Con- } \\
\text { trols }\end{array}$ & $\chi^{2}$ & $\begin{array}{l}\text { p } \\
\text { value }\end{array}$ \\
\hline rs11639998 & intron 1 & C/C & 86 & 67 & 0.39 & 0.94 \\
& & C/G & 74 & 50 & & \\
\hline rs11643057 & intron 1 & C/C & 21 & 14 & 2.04 & 0.56 \\
& & C/T & 68 & 48 & & \\
\hline rs1362626 & \multirow{2}{*}{ intron 1 } & C/C & 19 & 12 & 0.93 & 0.82 \\
& & C/G & 75 & 50 & & \\
& & G/G & 83 & 67 & & \\
\hline rs11076834 & intron 1 & C/C & 87 & 69 & 1.09 & 0.78 \\
& & C/G & 65 & 47 & & \\
& & G/G & 23 & 14 & & \\
\hline rs1051308 & \multirow{2}{*}{ 3' UTR $^{\prime}$ A/A } & 91 & 71 & 3.40 & 0.33 \\
& & A/G & 66 & 45 & & \\
& & G/G & 19 & 16 & & \\
\hline
\end{tabular}

approved by the Ethics Committee of the Juntendo University School of Medicine.

Information on the single nucleotide polymorphisms (SNPs) was obtained from the SNP database established by the National Center for Biotechnology Information. Five SNPs of the HMOX1 gene and five SNPs of the HMOX2 gene were genotyped using TaqMan technology on an ABI7500 system (Applied Biosystems, Foster City, Calif., USA). All probes and primers were designed by the Assay-by-Design ${ }^{\mathrm{TM}}$ service of Applied Biosystems. The standard polymerase chain reaction was carried out using the TaqMan Universal PCR Master Mix reagent kit in a $10-\mu$ l volume. For all the samples, ApoE genotypes were determined as described previously [22].

Hardy-Weinberg equilibrium tests were carried out for all SNPs for both cases and controls. Statistical analyses of the AD cases divided into the subgroups, ApoE4 positive and negative, were also carried out. The genotypic distribution of the $\mathrm{AD}$ groups and their respective controls were compared using Fisher's exact probability test ( $p<0.05$ was considered statistically significant). Linkage disequilibrium between the SNPs was analyzed using the estimated haplotype program.

\section{Results}

Our sample set has the power to detect an odds ratio of at least 1.90 , assuming a significance level of 0.05 , power of 0.80 and an exposure frequency of 0.30 in controls. Five SNPs of the HMOX1 gene and five SNPs of the HMOX2 
Table 3. Frequencies of the polymorphisms of the HMOX1 and the HMOX2 genes stratified according to ApoE status

\begin{tabular}{|c|c|c|c|c|c|c|c|c|c|c|}
\hline & & & \multicolumn{4}{|c|}{ ApoE4 positive } & \multicolumn{4}{|c|}{ ApoE4 negative } \\
\hline & & & $\mathrm{AD}$ & controls & $\chi^{2}$ & $\mathrm{p}$ value & $\mathrm{AD}$ & controls & $x^{2}$ & $\mathrm{p}$ value \\
\hline $\begin{array}{l}\text { HMOX1 } \\
\text { rs2071747 }\end{array}$ & $\begin{array}{l}\text { exon } 1 \\
(\mathrm{H} / \mathrm{D})\end{array}$ & $\begin{array}{l}\mathrm{C} / \mathrm{C} \\
\mathrm{C} / \mathrm{G} \\
\mathrm{G} / \mathrm{G}\end{array}$ & $\begin{array}{r}0 \\
11 \\
63\end{array}$ & $\begin{array}{r}0 \\
6 \\
27\end{array}$ & 0.19 & 0.66 & $\begin{array}{r}1 \\
21 \\
82\end{array}$ & $\begin{array}{r}2 \\
12 \\
83\end{array}$ & 2.55 & 0.28 \\
\hline rs2071748 & intron 1 & $\begin{array}{l}\mathrm{A} / \mathrm{A} \\
\mathrm{A} / \mathrm{G} \\
\mathrm{G} / \mathrm{G}\end{array}$ & $\begin{array}{l}16 \\
45 \\
14\end{array}$ & $\begin{array}{r}11 \\
14 \\
8\end{array}$ & 2.97 & 0.23 & $\begin{array}{l}21 \\
57 \\
27\end{array}$ & $\begin{array}{l}22 \\
52 \\
23\end{array}$ & 0.26 & 0.88 \\
\hline rs2071749 & intron 3 & $\begin{array}{l}\mathrm{A} / \mathrm{A} \\
\mathrm{A} / \mathrm{G} \\
\mathrm{G} / \mathrm{G}\end{array}$ & $\begin{array}{r}4 \\
36 \\
35\end{array}$ & $\begin{array}{r}6 \\
12 \\
15\end{array}$ & 4.79 & 0.09 & $\begin{array}{r}8 \\
55 \\
42\end{array}$ & $\begin{array}{l}11 \\
49 \\
37\end{array}$ & 0.82 & 0.66 \\
\hline rs5755720 & intron 4 & $\begin{array}{l}\mathrm{A} / \mathrm{A} \\
\mathrm{A} / \mathrm{G} \\
\mathrm{G} / \mathrm{G}\end{array}$ & $\begin{array}{l}18 \\
41 \\
16\end{array}$ & $\begin{array}{r}6 \\
17 \\
10\end{array}$ & 1.16 & 0.56 & $\begin{array}{l}29 \\
57 \\
14\end{array}$ & $\begin{array}{l}32 \\
45 \\
20\end{array}$ & 7.31 & 0.06 \\
\hline rs5995098 & intron 4 & $\begin{array}{l}\mathrm{C} / \mathrm{C} \\
\mathrm{C} / \mathrm{G} \\
\mathrm{G} / \mathrm{G}\end{array}$ & $\begin{array}{l}17 \\
40 \\
18\end{array}$ & $\begin{array}{r}8 \\
15 \\
10\end{array}$ & 0.66 & 0.72 & $\begin{array}{l}31 \\
60 \\
14\end{array}$ & $\begin{array}{l}33 \\
44 \\
20\end{array}$ & 3.27 & 0.19 \\
\hline $\begin{array}{l}\text { HMOX2 } \\
\text { rs11639998 }\end{array}$ & intron 1 & $\begin{array}{l}\mathrm{C} / \mathrm{C} \\
\mathrm{C} / \mathrm{G} \\
\mathrm{G} / \mathrm{G}\end{array}$ & $\begin{array}{r}36 \\
33 \\
5\end{array}$ & $\begin{array}{r}14 \\
17 \\
2\end{array}$ & 0.89 & 0.83 & $\begin{array}{l}50 \\
41 \\
14\end{array}$ & $\begin{array}{l}53 \\
31 \\
12\end{array}$ & 2.32 & 0.51 \\
\hline rs11643057 & intron 1 & $\begin{array}{l}\mathrm{C} / \mathrm{C} \\
\mathrm{C} / \mathrm{T} \\
\mathrm{T} / \mathrm{T}\end{array}$ & $\begin{array}{r}6 \\
30 \\
38\end{array}$ & $\begin{array}{r}1 \\
17 \\
15\end{array}$ & 2.14 & 0.54 & $\begin{array}{l}15 \\
38 \\
48\end{array}$ & $\begin{array}{l}13 \\
29 \\
54\end{array}$ & 3.19 & 0.36 \\
\hline rs1362626 & intron 1 & $\begin{array}{l}\mathrm{C} / \mathrm{C} \\
\mathrm{C} / \mathrm{G} \\
\mathrm{G} / \mathrm{G}\end{array}$ & $\begin{array}{r}5 \\
35 \\
34\end{array}$ & $\begin{array}{r}1 \\
18 \\
14\end{array}$ & 1.32 & 0.72 & $\begin{array}{l}14 \\
40 \\
49\end{array}$ & $\begin{array}{l}11 \\
30 \\
53\end{array}$ & 1.83 & 0.61 \\
\hline rs11076834 & intron 1 & $\begin{array}{l}\mathrm{C} / \mathrm{C} \\
\mathrm{C} / \mathrm{G} \\
\mathrm{G} / \mathrm{G}\end{array}$ & $\begin{array}{r}39 \\
29 \\
6\end{array}$ & $\begin{array}{r}15 \\
16 \\
1\end{array}$ & 1.96 & 0.58 & $\begin{array}{l}48 \\
36 \\
17\end{array}$ & $\begin{array}{l}54 \\
29 \\
13\end{array}$ & 3.13 & 0.37 \\
\hline rs1051308 & 3' UTR & $\begin{array}{l}\mathrm{A} / \mathrm{A} \\
\mathrm{A} / \mathrm{G} \\
\mathrm{G} / \mathrm{G}\end{array}$ & $\begin{array}{r}40 \\
29 \\
4\end{array}$ & $\begin{array}{r}15 \\
16 \\
2\end{array}$ & 1.71 & 0.63 & $\begin{array}{l}51 \\
37 \\
15\end{array}$ & $\begin{array}{l}56 \\
27 \\
14\end{array}$ & 3.52 & 0.32 \\
\hline
\end{tabular}

gene were genotyped in our Japanese samples. The genotypes of all the SNPs were in Hardy-Weinberg equilibrium in our Japanese cases. The genotypic frequencies of each SNP for our cases and controls are shown in tables 1 and 2. There was no significant difference in the genotypic distribution for any polymorphism of the HMOX1 and HMOX2 genes. In addition, both the ApoE4-positive and -negative subgroups failed to show any genetic association between the SNPs and disease (table 3).

\section{Discussion}

Our case-control dataset has the statistical power to detect risk factors, such as ApoE4. For the HMOX1 gene, our results indicate that none of the polymorphisms, including one non-synonymous SNP, altered the risk for $\mathrm{AD}$ in our Japanese cohort. Our study also failed to detect any positive genetic association between HMOX1, ApoE and the disease. This is in agreement with a recent study,

Dement Geriatr Cogn Disord 2009;27:273-277 
which showed that a $(\mathrm{GT})_{\mathrm{n}}$ repeat microsatellite polymorphism of the HMOX1 gene did not affect the AD risk in a Japanese population [21]. However, a positive synergistic association was recently reported between an SNP in the promoter of the HMOX1 gene (rs2071746) together with SNPs of the liver $X$ receptor- $\beta$ (LXR- $\beta$ ) gene and $\mathrm{AD}$ [23]. We speculate that several factors may account for the different findings, such as differences in ethnic origin and differences in the location of the chosen SNPs. Although the datasets used in the microsatellite study and our study are from the same ethnic group, the pathological consequences of SNPs might differ from that of a microsatellite polymorphism. Although our study showed negative results, the non-synonymous $(\mathrm{H}>\mathrm{D})$ SNP in exon 1 (rs2071747) has been validated, is functionally important and is located close to the SNP rs2071746 mentioned above. Furthermore, a very recent study reported a positive synergistic association between rs2071747 with tau polymorphisms and AD [24]. Therefore, combined with the fact that $\mathrm{AD}$ is a genetically complex disease, further genetic studies of rs2071747 and the surrounding region would be important.
To the best of our knowledge, this is the first study evaluating the association between SNPs of the HMOX2 gene and $\mathrm{AD}$. The five intronic SNPs chosen cover almost the entire region of the gene. We confirmed the tight linkage disequilibrium among the five SNPs in our Japanese cohort (data not shown). Recent papers have suggested that decreased HMOX2 activity might be associated with chronic neurodegenerative disorders $[25,26]$. Although we did not find any positive results for the HMOX2 gene and $A D$, replication studies with other ethnic groups are needed to clarify the relationship between the HMOX2 gene and AD.

\section{Acknowledgments}

This study was in part funded by a High Technology Research Center grant from the Japanese Ministry of Education, Culture, Sports, Science and Technology and by a research grant from the Japanese Ministry of Health, Labor and Welfare of Japan. We are grateful for the technical assistance of Ms. K. Yamamoto and Ms. S. Itakura.

\section{References}

1 Sayre LM, Perry G, Harris PL, Liu Y, Schubert KA, Smith MA: In situ oxidative catalysis by neurofibrillary tangles and senile plaques in Alzheimer's disease: a central role for bound transition metals. J Neurochem 2000;74: 270-279.

-2 Zecca L, Youdim MB, Riederer P, Connor JR, Crichton RR: Iron, brain ageing and neurodegenerative disorders. Nat Rev Neurosci 2004;5:863-873.

-3 Atamna H, Frey WH 2nd: A role for heme in Alzheimer's disease: heme binds amyloid beta and has altered metabolism. Proc Natl Acad Sci USA 2004;101:11153-11158.

-4 Bodovitz S, Falduto MT, Frail DE, Klein WL: Iron levels modulate alpha-secretase cleavage of amyloid precursor protein. J Neurochem 1995;64:307-315.

-5 Rogers JT, Randall JD, Cahill CM, Eder PS, Huang X, Gunshin H, et al: An iron-responsive element type II in the $5^{\prime}$-untranslated region of the Alzheimer's amyloid precursor protein transcript. J Biol Chem 2002;277: 45518-45528.

6 Takahashi M, Dore S, Ferris CD, Tomita T, Sawa A, Wolosker H, et al: Amyloid precursor proteins inhibit heme oxygenase activity and augment neurotoxicity in Alzheimer's disease. Neuron 2000;28:461-473.
7 Lehmann DJ, Worwood M, Ellis R, Wimhurst VL, Merryweather-Clarke AT, Warden $\mathrm{DR}$, et al: Iron genes, iron load and risk of Alzheimer's disease. J Med Genet 2006;43: e52.

-8 Morgan NV, Westaway SK, Morton JE, Gregory A, Gissen P, Sonek S, et al: PLA2G6, encoding a phospholipase A2, is mutated in neurodegenerative disorders with high brain iron. Nat Genet 2006;38:752-754.

-9 Berlin D, Chong G, Chertkow H, Bergman H, Phillips NA, Schipper HM: Evaluation of HFE (hemochromatosis) mutations as genetic modifiers in sporadic AD and MCI. Neurobiol Aging 2004;25:465-474.

10 Hussain RI, Ballard CG, Edwardson JA, Morris CM: Transferrin gene polymorphism in Alzheimer's disease and dementia with Lewy bodies in humans. Neurosci Lett 2002; 317:13-16.

11 Moalem S, Percy ME, Andrews DF, Kruck TP, Wong S, Dalton AJ, et al: Are hereditary hemochromatosis mutations involved in Alzheimer disease? Am J Med Genet 2000; 93:58-66

12 Namekata K, Imagawa M, Terashi A, Ohta S, Oyama F, Ihara Y: Association of transferrin C2 allele with late-onset Alzheimer's disease. Hum Genet 1997;101:126-129.
13 Pulliam JF, Jennings CD, Kryscio RJ, Davis DG, Wilson D, Montine TJ, et al: Association of HFE mutations with neurodegeneration and oxidative stress in Alzheimer's disease and correlation with APOE. Am J Med Genet B Neuropsychiatr Genet 2003;119:48-53.

14 Robson KJ, Lehmann DJ, Wimhurst VL, Livesey KJ, Combrinck M, MerryweatherClarke AT, et al: Synergy between the C2 allele of transferrin and the $\mathrm{C} 282 \mathrm{Y}$ allele of the haemochromatosis gene (HFE) as risk factors for developing Alzheimer's disease. J Med Genet 2004;41:261-265.

15 Zatta P, Messori L, Mauri P, van Rensburg SJ, van Zyl J, Gabrielli S, et al: The C2 variant of human serum transferrin retains the iron binding properties of the native protein. Biochim Biophys Acta 2005;1741:264-270.

16 Schipper HM: Heme oxygenase expression in human central nervous system disorders. Free Radic Biol Med 2004;37:1995-2011.

17 Schipper HM: Heme oxygenase-1: role in brain aging and neurodegeneration. Exp Gerontol 2000;35:821-830.

-18 Schipper HM, Bennett DA, Liberman A, Bienias JL, Schneider JA, Kelly J, et al: Glial heme oxygenase- 1 expression in Alzheimer disease and mild cognitive impairment. Neurobiol Aging 2006;27:252-261. 
19 Smith MA, Kutty RK, Richey PL, Yan SD, Stern D, Chader GJ, et al: Heme oxygenase-1 is associated with the neurofibrillary pathology of Alzheimer's disease. Am J Pathol 1994;145:42-47.

20 Parfenova H, Leffler CW: Cerebroprotective functions of HO-2. Curr Pharm Des 2008; 14 : 443-453.

-21 Kimpara T, Takeda A, Watanabe K, Itoyama Y, Ikawa S, Watanabe M, et al: Microsatellite polymorphism in the human heme oxygenase-1 gene promoter and its application in association studies with Alzheimer and Parkinson disease. Hum Genet 1997;100: 145-147.
22 Wenham PR, Newton CR, Price WH: Analysis of apolipoprotein E genotypes by the Amplification Refractory Mutation System. Clin Chem 1991;37:241-244.

23 Infante J, Rodriguez-Rodriguez E, Mateo I, Llorca J, Vazquez-Higuera JL, Berciano J, et al: Gene-gene interaction between heme oxygenase- 1 and liver $\mathrm{X}$ receptor-beta and Alzheimer's disease risk. Neurobiol Aging, 2008, E-pub ahead of print.
24 Mateo I, Sanchez-Juan P, Rodriguez-Rodriguez E, Infante J, Vazquez-Higuera JL, Garcia-Gorostiaga I, et al: Synergistic effect of heme oxygenase- 1 and tau genetic variants on Alzheimer's disease risk. Dement Geriatr Cogn Disord 2008;26:339-342.

25 Dore S: Decreased activity of the antioxidant heme oxygenase enzyme: implications in ischemia and in Alzheimer's disease. Free Radic Biol Med 2002;32:1276-1282.

26 Wang J, Zhuang H, Dore S: Heme oxygenase 2 is neuroprotective against intracerebral hemorrhage. Neurobiol Dis 2006;22:473476. 